PENENTUAN NASABAH PENERIMA REWARD PRODUK GOLD DENGAN METODE SIMPLE ADDITIVE WEIGHTING (SAW) STUDI KASUS : PT. PINJAM INDONESIA

Riki Ruli A. Siregar; Faizal Fachrurrozi

IMPLEMENTASI METODE BACKWARD CHAINING PADA DATA WAREHOUSE DAOP 1 JAKARTA PT. KAI (PERSERO) Rakhmat Arianto; Chandra Bagus Sugiarto

IMPLEMENTASI METODE DETEKSI TEPI CANNY PADA OBJEK SEBAGAI MODEL KEAMANAN APLIKASI PADA SMARTPHONE ANDROID

Abdul Haris; Andi Prasetyo

ANALISA DATA DAN PERANCANGAN APLIKASI SERVICE PELANGGAN PT. JNE UNTUK PENINGKATAN KUALITAS LAYANAN

Dewi Arianti Wulandari; Sonny Syahrindra Putra

JARINGAN AD-HOC VEHICULAR (VANET) : TINJAUAN TENTANG ARSITEKTUR, KARAKTERISTIK, APLIKASI, DAN PROTOKOL MEDIUMACCESS CONTROL (MAC)

Rosida Nur Aziza

PERANCANGAN APLIKASI PENJADWALAN MATA KULIAH MENGGUNAKAN METODE CONSTRAINT PROGRAMMING Syam Gunawan

RANCANGAN TATA KELOLA PEREMAJAAN RUANG KELAS DIREKTORAT PEMBINAAN SEKOLAH DASAR

Ratna Mutu Manikam; Purwanto

PENGEMBANGAN AMORIK MENGGUNAKAN METODE GARIS SINGGUNG TERHADAP DUA LINGKARAN DAN PERSAMAAN KURVA BEZIER ORDE DUA.

Darma Rusjidi

OPTIMALISASI PENGAMBILAN KEPUTUSAN PENILAIAN KINERJA DOSEN PADA PERGURUAN TINGGI ISLAM XYZ MENGGUNAKAN AHP (ANALYTICAL HIERARCHY PROCESS)

Rahma Farah Ningrum

PENGAMANAN SMS PADA TELEPON SELULER BERBASIS ANDROID MENGGUNAKAN ALGORITMA TRIPLE DES Raka Yusuf; $M$. Rival Suheri

APLIKASI LATIHAN SOAL UJIAN TEORI SURAT IZIN MENGEMUDI BERBASIS WEB Harni Kusniyati; Raka Yusuf; Andri Setiawan

RANCANG BANGUN SIMULASI TERJADINYA LISTRIK DENGAN SUMBER DAYA SAMPAH BERBASIS MULTIMEDIA (STUDI KASUS : TPST BANTAR GEBANG)

Yasni Djamain; Ika Fitriyani Putri

\begin{tabular}{|c|c|c|c|c|c|c|}
\hline \multirow{2}{*}{ 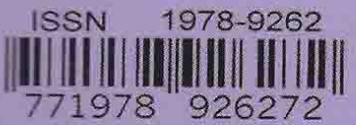 } & \multicolumn{6}{|c|}{ SEKOLAH TINGGI TEKNIK - PLN (STT-PLN) } \\
\hline & PETIR & VOL. 9 & NO. 1 & HAL. 1 - 87 & JAKARTA, MARET 2016 & ISSN $1978-9262$ \\
\hline
\end{tabular}




\title{
RANCANG BANGUN SIMULASI TERJADINYA LISTRIK DENGAN SUMBER DAYA SAMPAH BERBASIS MULTIMEDIA (STUDI KASUS : TPST BANTAR GEBANG)
}

\author{
Yasni Djamain; Ika Fitriyani Putri \\ Program Studi Teknik Informatika Sekolah Tinggi Teknik PLN Jakarta \\ yasnidj@gmail.com; ikafitriyani9@yahoo.com
}

\begin{abstract}
Learning or material on processing waste to produce electricity is needed because demand for electricity increases, while uncontrolled trash. Uncontrolled increase in litter causes uncontrolled pollution in the air anyway. Coupled with the fossil fuel emissions that are contributing to pollution and environmental pollution are greatest. Processing environmentally friendly fuels such as waste must be developed. Learning about the waste that exists today only still lacking and is still text-based or in book form. This leads to a lack of public interest to learn the material on waste management. The existence of this application, a solution to these problems. This application is designed in the form of exciting multimedia learning so as to increase public interest in the field of waste management. In addition in the form of multimedia, this application is also easy to operate, because the location and navigation menu uncomplicated. Waste processing in this application refers to the existing landfill gas systems in Power Plant Waste (PLTSa) Bantargebang.
\end{abstract}

Keywords: garbage, electricity, PLTSa, multimedia

\section{PENDAHULUAN}

\subsection{Latar Belakang}

Listrik merupakan salah satu sumber kehidupan bahkan termasuk kebutuhan primer manusia. Listrik menjadi kebutuhan yang tak bisa dipisahkan dari kehidupan manusia sejak ditemukan tahun 1821. Apalagi di era yang serba elektronik seperti sekarang ini, kebutuhan akan listrik semakin meningkat pesat. Hal ini tidak akan terpenuhi tanpa adanya sumber daya dan sarana yang mencukupi.

Sumber daya yang digunakan selama ini yang terbesar berasal dari energi fosil. Fosil merupakan salah satu sumber daya terbesar di Indonesia. Namun energi fosil merupakan sumber daya yang tidak dapat diperbaharui, sehingga semakin lama digunakan persediaan sumber tersebut semakin menipis dan bahkan bisa habis. Selain persediaan yang semakin menipis, emisi bahan bakar fosil juga penyumbang polusi dan pencemaran lingkungan yang terbesar. Hal ini pula yang menyebabkan adanya lubang pada lapisan ozon dan akibatnya terjadi pemanasan global atau global warming.

Untuk mengatasi masalah-masalah tersebut, kita harus mencari energi alternatif sebagai pengganti energi fosil. Energi alternatif haruslah berasal dari sumber energi yang bisa diperbaharui artinya tidak akan habis walaupun digunakan sebesar apapun. Salah satu sumber energi alternatif adalah sampah. Sampah merupakan benda yang paling dekat dengan kehidupan manusia dan jumlah atau volume sampah sebanding dengan tingkat konsumsi kita terhadap barang/material yang kita gunakan sehari-hari. Peningkatan jumlah penduduk dan gaya hidup sangat berpengaruh pada volume sampah.
Penumpukkan sampah juga bisa menjadi masalah bagi kelangsungan hidup manusia dan lingkungan jika tidak diolah dan dimanfaatkan. Namun hal ini tidak sebanding dengan sumber daya manusia di Indonesia. Masih banyak masyarakat yang belum mengetahui bagaimana mengolah dan memanfaatkan sampah. Dan minimnya minat membaca masyarakat juga menjadi kendala untuk memperkenalkan manfaat dan cara mengolah sampah.

Sebuah penelitian menyatakan bahwa memori manusia terdiri dari $70 \%$ visual, $20 \%$ audio dan $10 \%$ text.

Oleh karena itu Aplikasi Simulasi Terjadinya Listrik dengan Sumber Daya Sampah Berbasis Multimedia ini dirancang, agar lebih menarik minat masyarakat untuk mempelajari bagaimana cara mengolah sampah dan dapat dengan mudah mempraktikkannya dan bisa menggunakan manfaatnya.

\subsection{Batasan Masalah}

Penulis menyadari begitu banyak argumen tentang Pembangkit Listrik Tenaga Sampah. Oleh karena itu, penulis memberikan batasan-batasan guna mengarahkan penulisan sehingga informasi dari tulisan ini dapat tersampaikan.

Adapun batasan-batasan yang dimaksudadalah :

1. Alur kerja pembangkit listrik tenaga sampah di TPST Bantar Gebang melalui sumur vertical.

2. Gambaran perbandingan banyak gas yang masuk dengan listrik yang dihasilkan.

\subsection{Rumusan Masalah}

Berdasarkan latar belakang dan batasan masalah pemilihan judul di atas, dapat dirumuskan permasalahan sebagai berikut : 
1. Bagaimana membuat simulasi pengolahan sampah menjadi listrik di TPST Bantar Gebang?

2. Bagaimana perbandingan rata-rata gas yang masuk dengan listrik yang dihasilkan?

\subsection{Tujuan}

Adapun tujuan dari pembuatan aplikasi simulasi pembangkit listrik tenaga sampah ini adalah untuk memberikan gambaran rinci bagaimana terjadinya listrik dari sumber daya sampah di PLTSa Bantar Gebang dan gambaran perbandingan banyak gas dengan listrik yang dihasilkan

\subsection{Manfaat Penelitian}

1. Memberikan kemudahan bagi masyarakat untuk mengetahui proses perubahan dari sampah menjadi listrik.

2. Meningkatkan minat masyarakat untuk mempelajari proses terjadinya listrik dengan sumber daya sampah karena apikasi ini dirancang dalam bentuk multimedia yang menarik.

\subsection{Metodologi Penelitian}

Adapun metodologi penelitian yang digunakan dalam mengatasi masalah masalah diatas adalah dengan metodologi prototype atau prototyping.

\section{TINJAUAN PUSTAKA}

\subsection{Simulasi}

Dalam Kamus Besar Bahasa Indonesia, kata simulasi diartikan sebagai penggambaran suatu sistem atau proses dengan peragaan berupa model statistik atau pemeranan. Dengan kata lain simulasi merupakan meniru suatu system dalam bentuk yang lebih sederhana. Simulasi bukan hanya solusi dengan menggunakan model (data atau miniatur) yang dibuat sedemikian rupa untuk menghasilkan nilai tertentu. Simulasi dapat menduga perilaku suatu sistem yang diamati dengan menggunakan data hasil pengamatan yang dilakukan dalam waktu tertentu. Dari data hasil pengamatan tersebut maka dapat dibuat suatu prediksi dan selanjutnya memutuskan tindakan apa yang akan dilakukan.

Pendekatan simulasi diawali dengan pembangunan model sistem nyata. Model tersebut harus dapat menunjukkan bagaimana berbagai komponen dalam sistem saling berinteraksi sehingga benar-benar menggambarkan perilaku sistem. Setelah model dibuat maka model tersebut ditransformasikan ke dalam program komputer sehingga memungkinkan untuk disimulasikan.

\subsection{Sampah}

\subsubsection{Definisi Sampah}

Sampah merupakan material sisa baik dari hewan, manusia, maupun tumbuhan yang tidak terpakai lagi dan dilepaskan ke alam dalam bentuk padatan, cair ataupun gas.
Dalam kehidupan manusia, sampah dalam jumlah besar datang dari aktivitas industri (dikenal juga dengan sebutan limbah), misalnya pertambangan, manufaktur, dan konsumsi. Hampir semua produk industri akan menjadi sampah pada suatu waktu, dengan jumlah sampah yang kira-kira mirip dengan jumlah konsumsi.

"Sampah adalah bahan yang tidak mempunyai nilai atau tidak berharga untuk maksud biasa atau utama dalam pembikinan atau pemakaian barang rusak atau bercacat dalam pembikinan manufaktur atau materi berkelebihan atau ditolak atau buangan". (Kamus Istilah Lingkungan,1994).

Menurut Undang-undang Nomor 18 Tahun 2008 tentang Pengelolaan Sampah : sampah adalah sisa hasil kegiatan sehari-hari manusia dan/atau proses alam yang berbentuk padat.

\subsubsection{Jenis Sampah}

Berdasarkan sifat kimianya, sampah dibagi menjadi dua jenis yaitu :

1. Sampah Organik terdiri dari bahan-bahan penyusun tumbuhan dan hewan yang berasal dari alam.

2. Sampah Anorganik berasal dari sumber daya alam tak terbarui seperti mineral dan minyak bumi, atau dari proses industri.

Berdasarkan sifat fisiknya, sampah dibagi menjadi dua jenis yaitu :

1. Sampah Basah (garbage), yaitu sampah yang terdiri dari bahan organik dan mempunyai sifat mudah membusuk.

2. Sampah Kering, yaitu sampah yang tersusun dari bahan organik dan bahan anorganik, sifatnya lambat atau tidak membusuk dan dapat dibakar.

\subsection{PLTSa di TPST Bantar Gebang}

TPST Bantar Gebang berdiri di atas lahan seluas 110 hektare.Dan saat ini terdapat 3 zona penumpukkan sampah yang masing-masing zona memiliki luas 20-25 hektare.

TPST Bantar Gebang menerapkan metode Sanitary Landfill. Pemusnahan sampah dengan metode Sanitary Landfill adalah membuang dan menumpuk sampah ke suatu lokasi yang cekung, memadatkan sampah tersebut kemudian menutupnya dengan tanah. Pemusnahan sampah dengan metode Sanitary Landfill adalah membuang dan menumpuk sampah ke suatu lokasi yang cekung, memadatkan sampah tersebut kemudian menutupnya dengan tanah. (Pemkot Bekasi, 2009), metode ini dianggap dapat menghilangkan polusi udara. Volume sampah yang masuk ke TPST Bantar Gebang tersebut relatif menunjukkan peningkatan setiap tahunnya.Sampai saat ini sampah yang masuk dalam timbangan di TPST Bantar Gebang mencapai 6000-7000 ton per hari.

Awalnya, TPST Bantar Gebang menggunakan system open dumping. System ini tidak ramah lingkungan dan dapat mencemarkan tanah. 
Dampak bagi lingkungan

1. Air sampah merupakan limbah cair yang berasal dari sampah basah atau sampah organik yang terkena air hujan. Jika lindi tersebut tidak ditata dengan baik, maka dapat menyebar ke dalam tanah dan masuk ke aquifer air tanah yang dapat menyebabkan pencemaran air tanah

2. Penyumbatan badan air.

3. Cairan yang dihasilkan akibat proses penguraian (leachate) dapat mencemari sumber air.

4. Lahan yang luas akan tertutup oleh sampah dan tidak dapat digunakan untuk tujuan lain.

5. Gas yang dihasilkan dalam proses penguraian akan terperangkap di dalam tumpukan sampah dapat menimbulkan ledakan jika mencapai kadar dan tekanan tertentu.

6. Sungai dan pipa air minum mungkin teracuni karena bereaksi dengan zat-zat atau polutan sampah.

\section{Dampak bagi manusia}

1. Air sampah mengandung zat-zat berbahaya bagi tubuh seperti adanya kandungan $\mathrm{Hg}$, $\mathrm{H}_{2} \mathrm{~S}$, tergantung jenis sampah yang dibuang di TPA tersebut.

2. Merupakan sumber dan tempat perkembang biakan organisme penyebar penyakit.

Untuk mengurangi dampak yang demikian, maka dibangunlah sebuah pembangkit listik yang memanfaatkan gas metana dari dalam tumpukan sampah sebagai bahan bakar. Dimulai dari pembuatan sumur gas baik itu vertikal maupun horizontal. Setiap tumpukan sampah ditutup dengan lapisan geo membran dan dibantu oleh pompa yang berguna untuk mengurangi air yang ada dalam sumur gas.

Dalam sumur vertical, diletakkan sebuah pipa yang berukuran panjang kira-kira 12-15meter.8 meter paling dasar dibuat berlubang dan yang muncul diluar permukaan sekitar 1-1.5 meter. Pipa ini dihubungkan ke sebuah pipa yang berukuran lebih besar yang disebut pipa header yang langsung terhubung ke pembangkit.

Instalasi pembangkit listrik tenaga sampah yang ada di TPST Bantar Gebang dimulai dari Kondensor yang berguna untuk memisahkan gas dari cairan yang dibawanya dari landfill.Dalam instalasi ini, terdapat 3 kondensor yaitu sebelum dan sesudah chiller lalu setelah blower. Hal ini dilakukan untuk memastikan bahwa benar-benar tidak ada cairan dalam gas yang akan masuk ke engine.

Chiller, berfungsi mendinginkan temperature gas sebelum masuk ke mesin atau engine untuk menghindari kerusakan pada mesin.Temperature gas yang keluar dari chiller adalah $10^{\circ} \mathrm{C}$ dari temperature awal yang mencapai $40^{\circ} \mathrm{C}$.

Blower, membantu dalam proses pengambilan gas dari zona. Cara kerjanya seperti sebuah vacum, yakni menghisap/menarik udara sekitar. Tanpa adanya blower ini, gas dari zona akan sulit mencapai tujuannya.
Langkah selanjutnya yaitu, gas masuk ke Gas Engine. Gas engine yang digunakan disini terdapat 2 type yaitu Jenbacher dan MWM dengan kapsitas dan setting yang berbeda. Kedua mesin ini diatur sedeminikan rupa agar secara otomatis akan berhenti saat jumlah gas tidak memenuhi kriteria. Untuk mesin Jenbacher, minimum jumlah gas metana yang masuk adalah $40 \%$, sedangkan mesin MWM, minimum gas metana yang masuk yaitu $45 \%$.

Kedua engine ini bekerja berdasarkan cara kerja engine 4 tak, yaitu: langkah hisap, langkah kompressi, langkah tenaga dan langkah buang.

Pada langkah hisap, Valve intake (hisap) akan membuka dan piston bergerak ke bawah. Dengan bergeraknya piston dari atas ke bawah maka udara yang ada dalam intake manifold akan terhisap memenuhi ruang bakar.

Langkah kompressi dimulai ketika campuran bahan bakar dinyalakan oleh busi. Dengan cepat campuran yang terbakar ini mermabat dan terjadilah ledakan yang tertahan oleh dinding kepala silinder sehingga menimbulkan tendangan balik bertekanan tinggi yang mendorong piston turun ke silinder bore. Gerakan linier dari piston ini dirubah menjadi gerak rotasi oleh Crankshaft. Energy rotasi diteruskan sebagai momentum menuju flywheel yang bukan hanya menghasilkan tenaga. Counter balance weight pada crankshaft membantu piston melakukan siklus berikutnya.

Langkah tenaga dimulai ketika campuran udara-bahan bakar dinyalakan oleh busi.Dengan cepat campuran yang terbakar ini merambat dan terjadilah ledakan yang tertahan oleh dinding kepala silinder sehingga menimbulkan tendangan balik bertekanan tinggi yang mendorong piston turun ke bawah.

Langkah buang menjadi sangat penting untuk menghasilkan operasi kinerja mesin yang lembut dan efisien.Piston bergerak mendorong gas sisa pembakaran keluar dari silinder menuju pipa knlapot. Proses ini harus dilakukan dengan total, dikarenakan sedikit saja terdapat gas sisa pembakaran yang tercampur bersama pemasukan gas baru akan mereduksi potensial tenaga yang dihasilkan.

Semua langkah yang telah disebutkan diatas merupakan awal bergeraknya generator.Energy mekanik yang keluar dari engine memutar sebuah poros yang dihubungkan ke generator. Akibat perputaran poros, magnet yang ada dalam main rotor berputar yang menimbulkan munculnya medan magnet. Hal inilah yang merupakan proses perubahan energy mekanik menjadi energy listrik.

Listrik yang keluar dari generator dihubungkan ke transformer.Transformer berfungsi menurunkan atau menaikkan tegangan.Dalam instalasi ini, digunakan transformer step down atau penurun tegangan.Listrik yang keluar dari transformer atau trafo kemudian didistribusikan ke gardu induk melalui kabel PLN bawah tanah.

Saat ini, PLTSa Bantar Gebang telah mampu memproduksi listrik sebesar $10 \mathrm{MW}$. Sementara itu, kapasitas penuh sebesar 26 MW ditargetkan tercapai pada 2023. 


\section{METODOLOGI PENELITIAN}

\subsection{Kerangka Pemikiran}

Untuk membuat pembahasan sistematis, penulis memerlukan kerangka pemikiran, seperti dibawah ini:

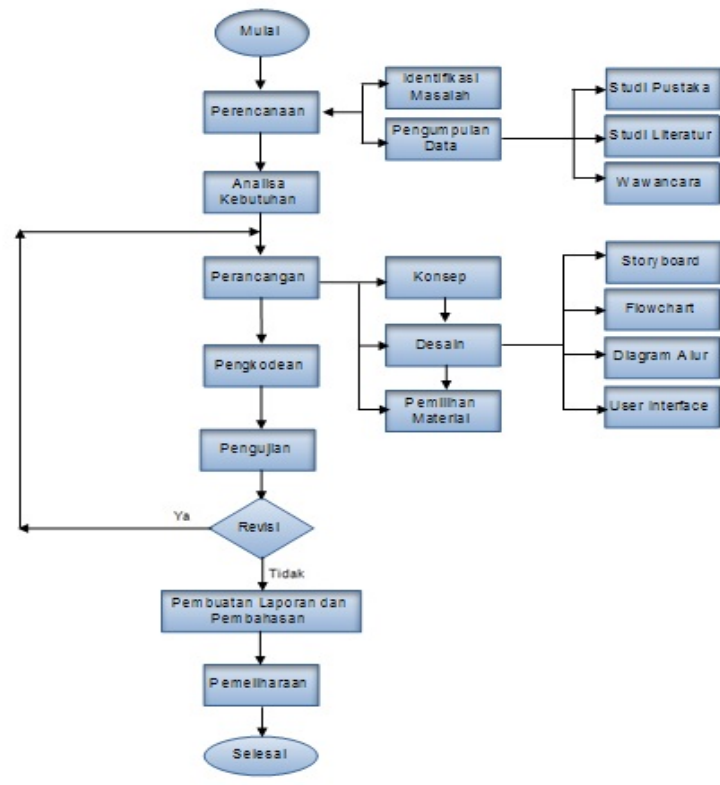

Gambar 1. Kerangka Penelitian

\subsubsection{Perencanaan}

Dalam tahap perencanaan ada 2 proses didalamnya, yaitu identifikasi masalah dan pengumpulan data.

a. Identifikasi Masalah dalam perancangan Simulasi Pengolahan Sampah Menjadi Listrik Berbasis Multimedia (Studi Kasus : TPST Bantar Gebang)" dimana dalam perancangannya menggunakan software Adobe Flash CS3 dan Microsoft Visual Basic sebagai interfacenya.

b. Pengumpulan Data dalam perancangan aplikasi ini penulis mulai dari studi pustaka sampai dengan studi literature dan wawancara serta observasi. Adapun alat dan bahan yang digunakan dalam pengumpulan data ini adalah camera, voice recorder (perekam suara), data statistik gas yang masuk dan listrik yang dihasilkan, data mengenai alur proses kerja PLTSa, kertas, pulpen dan Edraw Flowchart 5.

1. Studi pustaka dilakukan dengan membaca buku-buku referensi yang berhubungan dengan PLTSa, Adobe Flash, Microsoft Visual Basic 6.0 dan Multimedia seperti yang dilampirkan pada daftar pustaka.

2. Studi literature dilakukan dengan membaca dan mempelajari literature yang ada seperti makalah, jurnal, paper dan blog yang berhubungan dengan
PLTSa, vb 6.0, adobe flash dan multimedia.

3. Wawancara dan observasi penulis lakukan secara bersamaan. Penulis mewawancara karyawan di PLTSa sekaligus turun ke lapangan dalam hal ini observasi di tumpukan sampah yang akan dikelola. Selain itu, menelusuri tiap bagian dan melakukan pengambilan gambar berupa foto untuk mempermudah dalam pembuatan prototipe pada perancangan aplikasi.

\subsubsection{Analisa Kebutuhan Sistem}

Pada tahap ini penulis menganalisis permasalahan dan kebutuhan sistem yang diperlukan dalam pembuatan aplikasi seperti yang dilakukan di tahap identifikasi masalah.

\section{a. Analisa Sistem Berjalan}

Setelah observasi dan wawancara dapat dianalisa bahwa kerja PLTSa dimulai dari timbunan sampah yang menghasilkan gas metana.Gas inilah yang digunakan sebagai bahan bakar di dalam engine hingga menjadi listrik. Dikarenakan bahan bakar menggunakan gas, maka akan sulit memastikan banyak bahan bakar yang digunakan untuk menghasilkan jumlah listrik tertentu.

Dalam aplikasi ini, digambarkan skema kerja PLTSa yang memanfaatkat gas metana sebagai bahan bakar. Selain itu juga akan diperlihatkan gambaran bagaimana perbandingan gas yang masuk dengan listrik yang keluar dari data statistic yang ada.

\section{b. Analisa Permasalahan}

Permasalahan yang dihadapi tentang PLTSa yaitu seperti :

1. Kurangnya referensi mengenai PLTSa yang manfaat gas metana dari tumpukan sampah.

2. Referensi yang sudah ada hanya berbasis teks dan hal ini kurang menarik.

3. Masyarakat yang lebih tertarik terhadap media pembelajaran berbasis multimedia.

\section{c. Pemecahan Masalah}

Setelah mengamati dan memahami permasalahan, penulis memberikan solusi dari masalah yang muncul, yaitu :

1. Memberikan gambaran tentang pemanfaatan gas metana dengan membuat simulasi pengolahan sampah di PLTSa Bantar Gebang.

2. Memberikan edukasi yang lebih menarik dalam bentuk visual berbasis multimedia kepada masyarakat yang kurang menguasai bidang kelistrikan

\section{d. Analisa Kebutuhan Data}

Analisa terhadap kebutuhan data yang dibutuhkan dalam pembuatan aplikasi ini yaitu :

1. Alur Proses kerja PLTSa yang memanfaatkan gas metana sebagai bahan bakar.

2. Penjelasan fungsi komponen-komponen pada PLTSa 
3. Data perbandingan statistic antara gas dan listrik yang dihasilkan selama 3 bulan terakhir.

\section{e. Analisa Kebutuhan Proses}

Analisa terhadap kebutuhan proses yang akan dimunculkan pada aplikasi sesuai kebutuhan user sehingga user memperoleh informasi yang dibutuhkan. Proses yang ditampilkan dimulai dari membuka aplikasi. Pada halaman utama aplikasi akan ditawarkan beberapa menu diantaranya :

Tabel 1 : Analisa Kebutuhan Proses

\begin{tabular}{|l|l|l|}
\hline No & Nama Proses & De Proses \\
\hline 1. & $\begin{array}{l}\text { Simulasi } \\
\text { Proses PLTSa }\end{array}$ & $\begin{array}{l}\text { Memulai untuk } \\
\text { menjalankan } \\
\text { animasi alur proses } \\
\text { pltsa. }\end{array}$ \\
\hline 2. & $\begin{array}{l}\text { Simulasi } \\
\text { perbandingan bahan } \\
\text { dan listrik yang } \\
\text { dihasilkan }\end{array}$ & $\begin{array}{l}\text { Memulai untuk } \\
\text { menjalankan } \\
\text { simulasi } \\
\text { perbandingan } \\
\text { bahan dan listrik } \\
\text { yang dihasilkan. }\end{array}$ \\
\hline
\end{tabular}

\subsubsection{Perancangan}

Berdasarkan pertimbangan penulis, penelitian ini menggunakan metodologi menurut Luther, yang membahas tentang pengembangan aplikasi multimedia. Dalam bukunya, Multimedia Interaktif dengan Flash (Sutopo, 2003 : 32), Luther menjelaskan bahwa pengembangan aplikasi multimedia dilakukan dalam enam tahap, yaitu :

\section{a. Concept}

Pada pembuatan aplikasi ini bertujuan untuk memudahkan masyarakat dalam mengetahui proses produksi listrik dan perhitungan efisiensi PLTSa dengan sasaran pengguna aplikasi ini adalah para siswa smk yang mengambil pelajaran mengenai kelistrikan maupun mesin, mahasiswa yang mengambil matakuliah mengenai kelistrikan maupun mesin, pengunjung wisata education di PLTSa dan masyarakat luas yang ingin mengetahui dan memahami tentang PLTSa. Pembuatan aplikasi dimulai dari pembuatan ide atau gambaran animasi berdasarkan gambaran alur proses kerja PLTSa. Kemudian dilanjutkan dengan perancangan interface dan pembuatan source code untuk proses perhitungan efisiensi. Setelah selesai proses perhitungan, lalu animasi dimasukan ke dalam aplikasi tersebut. Sehingga pengguna dapat melakukan perhitungan efisiensi dan melihat simulasi alur proses PLTSa.

\section{b. Design}

Tahapan design atau perancangan, ini membuat spesifikasi mengenai arsitektur program, gaya, interface, dan kebutuhan material / bahan untuk program.Spesifikasi yang akan dibuat berdasarkan langkah berikut:

1. Perancangan storyboard

2. Perancangan bagan alir ( Flowchart view)

3. Perancangan antarmuka (User Interface )
Keterangan spesifikasi kebutuhan :

\section{Perancangan storyboard}

Storyboard adalah sejumlah gambar, didukung dengan catatan directional, yang membentuk script visual untuk sebuah Animasi. Mereka bertindak bagaikan sebuah konsep (ide) yang membantu dalam proses perencanaan, dan berfungsi untuk menguraikan peristiwa dan tindakan. Yang menentukan dari sebuah storyboard adalah pada adegan (scene), durasi (timing), kamera-shot, dan audio. Setiap gambar dalam storyboard harus menggambarkan dengan jelas elemen-elemen film yang meliputi gerakan kamera,adegan, pemotongan kamera (cut), dan dialog karakter

\section{b.2 Perancangan bagan alir ( Flowchart view )}

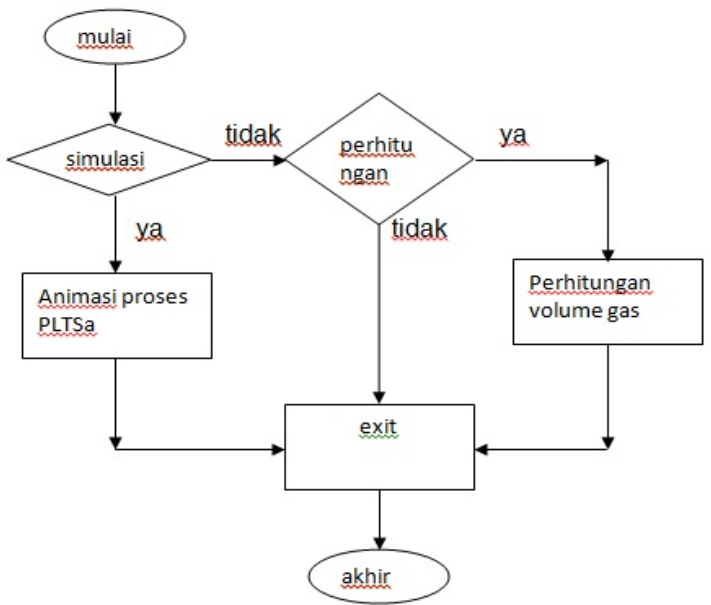

Gambar 2. Perancangan Flowchart

\section{b.3 Perancangan antarmuka ( User Interface )}

Halaman utama yang terdiri dari menu : Simulasi, Perhitungan, dan Exit.

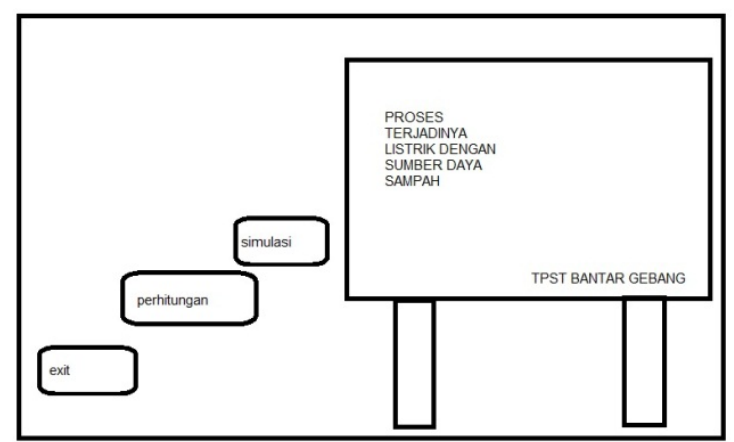

Gambar 3. Perancangan Interface Halaman Utama

Tampilan menu perhitungan 


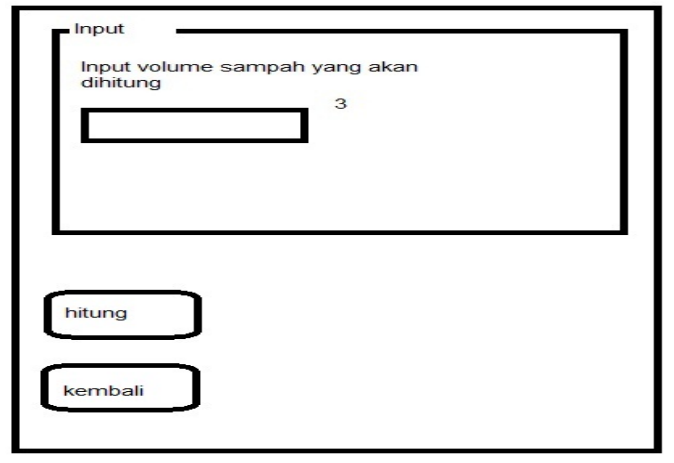

Gambar 4. Perancangan Interface Menu Perhitungan

Tampilan menu Hitung

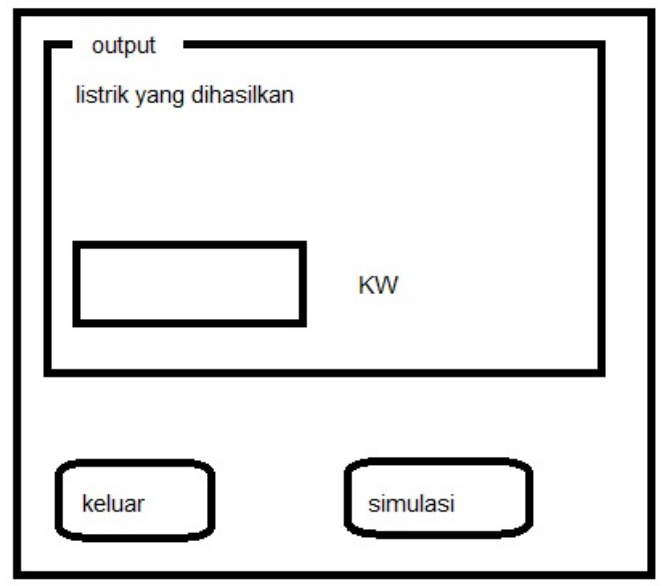

Gambar 5. Tampilan hasil Perhitungan

\section{c. Material Collecting}

Pengumpulan bahan yang sesuai dengan kebutuhan yang dilakukan. Tahapan ini dapat dilakukan bersama tahapan assembly. Namun, pada beberapa kasus hal ini tidak dapat dilakukan. Bahan ataupun data yang dibutuhkan dari pembuatan aplikasi ini adalah rumus efisiensi PLTSa dan alur proses kerja PLTSa.

\section{d. Assembly (Pembuatan)}

Semua obyek atau bahan multimedia dibuat pada tahap ini. Aplikasi berdasarkan pada tahapan design. Pembuatan akan dilakukan dengan bantuan software Adobe Flash CS3 Professional dan Visual Basic 6.0.

\section{e. Testing}

Tahapan ini dilakukan setelah tahapan assembly (pembuatan) dengan menjalankan aplikasi / program dan dilihat apakah ada kesalahan atau tidak. Tahap ini disebut juga sebagai tahap pengujian alpha dimana pengujian dilakukan oleh pembuat atau lingkungan pembuatnya sendiri. Setelah pengerjaan aplikasi selesai, akan dilakukan pengujian menggunakan PC atau Notebook.

\section{f. Distribution}

Aplikasi akan disimpan pada media penyimpanan. Jika media penyimpan tidak mencukupi menampung aplikasinya, kompresi terhadap aplikasi dapat dilakukan. Tahap ini juga disebut tahap evaluasi untuk pengembangan produk yang sudah jadi supaya lebih baik.

\subsection{Spesifikasi Perangkat Keras dan Perangkat Lunak}

Dalam proses pembuatan aplikasi ini, maka penulis menggunakan spesifikasi sebagai berikut:

1. Perangkat Keras

1 unit Laptop Axioo dengan spesifikasi berikut : Processor Intel (R) Core (TM) i5-2520M CPU @2.50 GHz 2.50 GHz, RAM berkapasitas $2.00 \mathrm{~GB}$

2. KebutuhanPerangkatLunak

Dalam pembuatan aplikasi ini penulis menggunakan perangkat lunak:

a. Windows 7 Ultimate 32-bit pada Laptop

b. Microsoft Visual Basic 6.0

Microsoft Visual Basic 6.0 adalah bahasa pemrograman yang digunakan untuk membuat aplikasi Windows yang berbasis grafis (GUI-Grapical User Interface). Microsoft Visual Basic merupakan eventdriven programming (pemrograman terkendali kejadian) artinya program menunggu sampai adanya respon dari pemakai berupa event atau kejadian tertentu (tombol diklik, menu dipilih, dan lain-lain).

c. Adobe Flash CS3

Adobe Flash (dahulu bernama Macromedia Flash) adalah salah satu perangkat lunak komputer yang merupakan produk unggulan Adobe Systems. Adobe Flash digunakan untuk membuat gambar vektor maupun animasi gambar tersebut. Berkas yang dihasilkan dari perangkat lunak ini mempunyai file extension .swf dan dapat diputar di penjelajah web yang telah dipasangi Adobe Flash Player. Flash menggunakan bahasa pemrograman bernama ActionScript yang muncul pertama kalinya pada Flash 5 .

\subsection{PEMBAHASAN}

Hasil Rancangan Aplikasi

Tampilan awal aplikasi

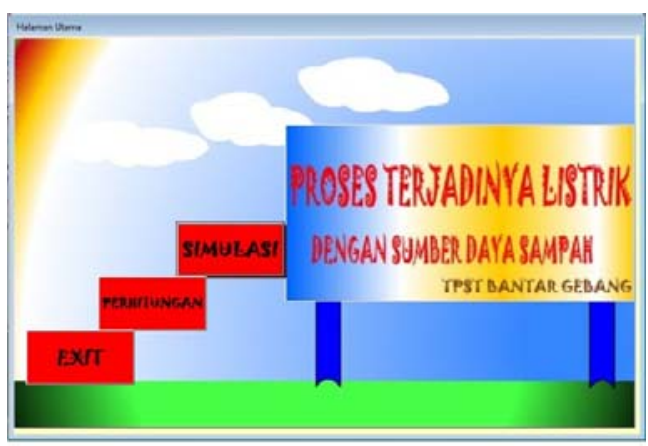

Gambar 6. Halaman Utama Aplikasi 
Pada Gambar 6, terlihat ada beberapa menu, yaitu menu simulasi, perhitungan dan exit. Menu simulasi akan menuju ke animasi proses kerja PLTSa Bantar Gebang, kemudian menu perhitungan yang bila diklik akan muncul halaman penginputan volume gas yang akan dihitung. Terakhir menu exit untuk keluar aplikasi.

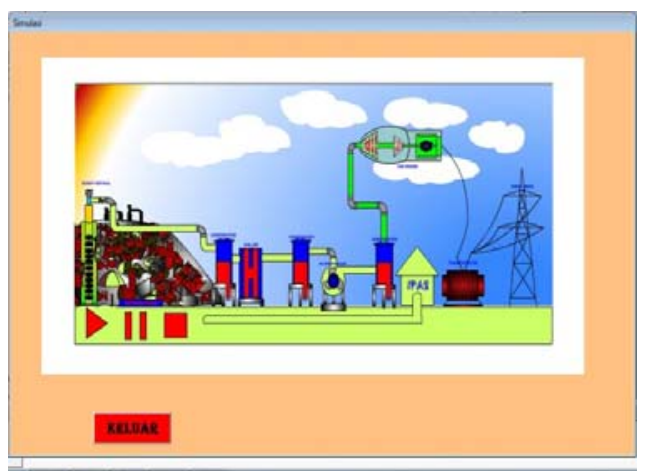

Gambar 7. Halaman Menu Simulasi

Pada Gambar 7 tampak halaman yang menampilkan animasi proses perubahan gas menjadi listrik di PLTSa Bantar Gebang. Didalamnya terdapat tombol play, pause dan stop. Tombol play untuk mulai menjalankan animasi. Tombol pause, untuk menghentikan sejenak animasi. Sedangkan tombol stop untuk menghentikan aplikasi. Dihalaman ini juga terdapat button keluar yang berguna jika user ingin keluar aplikasi.

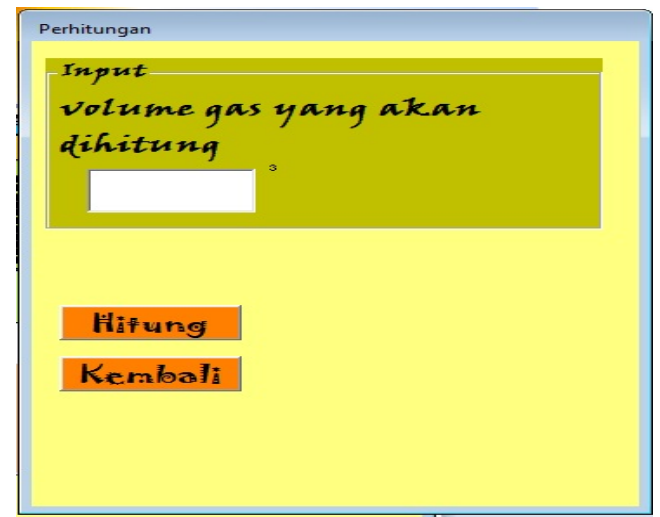

Gambar 8. Tampilan Menu Perhitungan

Pada Gambar 8 tampak satu textbox yang digunakan untuk menginputkan volume gas yang akan dihitung dalam satuan kubik. Selain itu dihalaman ini juga terdapat 2 tombol yaitu tombol hitung dan kembali.Tombol hitung untuk mengetahui hasil listrik berdasarkan volume gas yang sudah diinputkan.Sedangkan tombol kembali untuk kembali ke halaman utama.

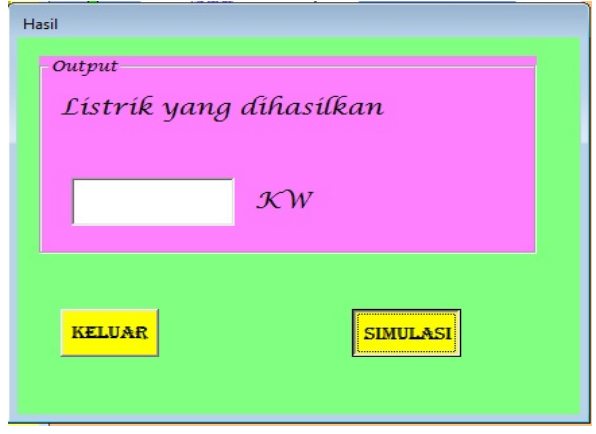

Gambar 9. Tampilan Tombol Hitung

Di halaman ini, terdapat satu textbox untuk menampilkan listrik yang dihasilkan dari perhitungan volume gas sebelumnya. Selain itu juga terdapat 2 tombol yaitu simulasi dan keluar. Simulasi untuk melihat animasi PLTSa. Sedangkan tombol keluar untuk menutup aplikasi.

\section{PENUTUP}

\subsection{Kesimpulan}

Dari uraian diatas dapat ditarik kesimpulan bahwa teknologi landfill gas tidak terlalu rumit dan mudah untuk dikembangkan.Namun membutuhkan lahan yang luas sebagai landfill pengambilan gas.Proses PLTSa di Bantar Gebang dimulai dari pengambilan gas methane melalui pipa yang diletakkan dalam sebuah sumur gas vertical yang sengaja dibuat dan pengisapan dibantu adanya blower. Sebelum masuk ke dalam blower, gas pertama-tama harus melewati kondensator dan chiller, baru kemudian melewati blower/vacuum. Stelah keluar dari vacuum, gas masuk kembali ke kondensator lalu kemudian masuk ke engine yang didalamnya terdapat 20 silinder yang memiliki 4 langkah atau disebut dengan msein 4 tak. Silindersilinder inilah yang menggerakkan sebuah poros yang terhubung ke generator.Dari generator listrik mentah masuk ke transformator baru kemudian dikirim ke gardu induk.

\section{DAFTAR PUSTAKA}

1. MADCOMS. 2008. Microsoft Visual Basic 6.0 untuk Pemula. Andi. Yogyakarta.

2. MADCOMS. 2012. Adobe Flash Professional CS5 untuk pemula. Andi. Yogyakarta.

3. Sutopo, Ariesto Hadi. 2003. Multimedia Interaktif Dengan Flash. Yogyakarta : Graha IImu.

4. http://sainsedutainment.blogspot.com/2011/10 /pembangkit-listrik-tenaga-sampah-pltsa.html.

5. http://muhammad_agus-

fkm10.web.unair.ac.id/artikel_detail-49663kuliah\%20-

Pengelolaan\%20Limbah\%20Sampah\%20(Op en\%20Damping\%20\&\%20Controlled\%20Lan dfill).html 